\title{
Studi Jenis Padi Pulut (Oryza glutinosa.L) Lokal Lahan Kering Di Kecamatan Kayan Hulu Kabupaten Sintang
}

\author{
Syarif Nizar Kartana \\ Fakultas Pertanian Universitas Kapuas Sintang \\ e-mail : icharngael2006@yahoo.com
}

\begin{abstract}
Abstrak: Penelitian ini bertujuan untuk mengetahui jenis-jenis padi pulut lokal lahan kering dan karakteristik agronomisnya secara sederhana di Kecamatan Kayan Hulu Kabupaten Sintang. Penelitian ini dilaksanakan dari bulan Februari sampai Juni 2017 di Kecamatan Kayan Hulu Kabupaten Sintang. Hasil penelitian menemukan delapan jenis padi pulut lokal lahan kering yang tumbuh di dua tipe lahan yaitu tepian sungai dan perbukitan. Kedelapan jenis padi pulut tersebut adalah pulut itam, pulut itam jabab, pulut kensurai, pulut lomak, pulut mentawak, pulut merah, pulut pantok manok, dan pulut paying.
\end{abstract}

Kata Kunci: Padi pulut lokal, lahan kering, kecamatan Kayan Hulu

\section{PENDAHULUAN}

Padi pulut atau dikenal masyarakat luas dengan padi ketan (Oryza glutinosa, L.) adalah salah satu jenis tanaman padi yang banyak ditanam oleh masyarakat di daerah Kecamatan Kayan Hulu Kabupaten Sintang. Penanaman padi pulut ini dilakukan setelah penanaman padi biasa. Buah muda padi pulut biasanya dipanen untuk dijadikan makanan ringan yang dikenal dengan istilah emping. Sedangkan panen tua atau panen setelah bulir padi masak digunakan untuk bahan penganan ringan seperti kue-kue tradisional dan bahan luluran untuk kecantikan.

Menurut Ningsih (2016), beras pulut atau ketan berdasarkan manfaatnya bagi kesehatan adalah memiliki sifat anti inflamasi dan kaya akan antioksidan. Beras ketan juga bermanfaat dalam menurunkan kadar gula dalam darah, meningkatkan daya ingat, mencegah anemia, membentuk otot, dan memperbaiki kerusakan sel hati.

Keberadaan padi pulut di Kecamatan Kayan Hulu merupakan salah satu kekayaan hayati yang perlu dilestarikan dan dikembangkan, karena dapat dijadikan sebagai sumber plasma nuftah dan sumber daya genetik. Langkah awal yang dapat dilakukan dalam upaya pelestarian jenis padi pulut ini adalah dengan melakukan pendataan tentang jenis yang ada serta karakteristik agronomis dari padi pulut tersebut karena data base tentang padi pulut ini masih sangat kurang. 
Penelitian ini bertujuan untuk mengetahui jenis-jenis padi pulut yang ada di Kecamatan Kayan Hulu Kabupaten Sintang serta karakteristik agronomis dari setiap padi pulut yang ada.

\section{TINJAUAN PUSTAKA}

\section{Pengertian Padi Pulut Lokal}

Padi pulut adalah padi yang menghasilkan beras ketan. Dalam Kamus Besar Bahasa Indonesia padi pulut berarti berasnya lengket atau lekat setelah dimasak. Secara morfologis tampak perbedaan yang nyata antara tanaman padi yang menghasilkan beras konsumsi dengan padi pulut yang menghasilkan beras ketan terutama warna daun.

Menurut Ifadatin dan Rusmiyanto (2006) padi pulut merupakan satu kelompok dengan padi non pulut. Sitaresmi, dkk (2013 ) menyatakan bahwa setiap varietas padi memiliki persamaan berbagai sifat, tetapi juga memiliki perbedaan karakter yang bersifat unik. Adanya persamaan dan perbedaan tersebut sering digunakan untuk mengetahui jauh dekatnya hubungan kekerabatan genetic antara varietas padi. Semakin banyak persamaan karakter tanaman padi semakin dekat hubungan kekerabatan genetiknya.

Rohaeni dan Hastini (2015), padi lokal merupakan salah satu sumber keragaman genetik yang memiliki sifat unik seperti ketahanan terhadap penyakit dan aroma serta kepulenan yang sangat disukai oleh masyarakat Indonesia umumnya. Menurut Ditjen Perbenihan (2010), sejak tahun 2000-an, jumlah padi lokal di lahan petani sudah sangat menurun. Hanya di beberapa wilayah tertentu varietas lokal masih ditanam petani karena mutu berasnya yang baik dengan harga jual yang tinggi. Erosi genetik tanaman padi akan semakin kritis apabila tidak dilakukan upaya pelestarian varietas lokal yang masih ada.

Sitaresmi, $\quad \mathrm{dkk}$ (2013) menyatakan bahwa plasma nutfah padi berupa varietas lokal memiliki keunggulan genetik tertentu. Padi lokal telah dibudidayakan secara turuntemurun sehingga genotip telah beradaptasi dengan baik pada berbagai kondisi lahan dan iklim spesifik di daerah pengembangannya. Padi lokal secara alami memiliki ketahanan terhadap hama dan penyakit, toleran terhadap cekaman abiotik, dan memiliki kualitas beras yang baik sehingga 
disenangi oleh banyak konsumen di tiap lokasi tumbuh dan berkembangnya.

Sitompul dan Guritno (1995) mengatakan bahwa penampilan bentuk tanaman dikendalikan oleh sifat genetik tanaman dibawah pengaruh faktorfaktor lingkungan. Faktor lingkungan yang diyakini dapat mempengaruhi terjadinya perubahan morfologi tanaman antara lain iklim, suhu, jenis tanah, kondisi tanah, ketinggian tempat, dan kelembaban.

\section{Kondisi Umum Lokasi Penelitian}

Kecamatan Kayan Hulu terletak di antara $0^{\circ} 08^{\prime}$ Lintang Utara serta $0^{\circ}$ 29' Lintang Selatan dan $111^{0} 57^{\prime}$ Bujur Timur serta $112^{0} 30^{\prime}$ Bujur Timur. Batas wilayah administratif Kecamatan Kayan Hulu yaitu:

Utara : Kecamatan Silat Kabupaten Kapuas Hulu.

Selatan: Kecamatan Ella Hilir dan Menukung Kabupaten

Melawi.

Timur : Kecamatan

Serawai,

Kabupaten Sintang

Barat : Kecamatan Kayan Hilir dan Nanga Pinoh Kabupaten Melawi.

Kecamatan Kayan Hulu memiliki luas wilayah sebesar 937,50
$\mathrm{Km}^{2}$ atau 4,33 persen dari luas wilayah Kabupaten Sintang dengan lahan tipologi datar seluas 29.573 ha dan berbukit 64.177 ha yang didominasi jenis tanah latosol dengan luasan 71550 $\mathrm{km}^{2}$ dan podsolik dengan luasan 22500 $\mathrm{km}^{2}$ (Badan Pertanahan Kabupaten Sintang ,2012). Luas lahan kering di Kecamatan Kayan Hulu yang diperuntukan sebagai ladang padi huma sekitar 1.350 Ha. Sebagian besar masyarakat desa yang dijadikan sampel dalam penelitian ini adalah petani yang menanam padi ladang atau lahan kering yaitu hampir 90\% (Badan Pusat Statistik Kayan Hulu,2016)

Menurut klasifikasi iklim Schmidt dan Ferguson iklim di Kabupaten Sintang tergolong tipe A, yaitu daerah bercurah hujan tinggi (iklim basah) dengan bulan basah antara 7 - 9 bulan dan bulan kering 2-3 bulan. Intensitas curah hujan yang tinggi dipengaruhi oleh keadaan daerah hutan tropis dan perbukitan yang disertai kelembaban udara yang cukup tinggi. Rata - rata bulanan curah hujan tertinggi terjadi pada bulan Oktober mencapai 414,9 $\mathrm{mm}$ dengan hari hujannya sebanyak 26 hari, sedangkan rata-rata curah hujan terendah pada bulan Agustus mencapai 110,3 mm 
dengan hari hujan sebanyak 14 hari.

Suhu udara rata-rata adalah $28,89^{\circ} \mathrm{C}$ dengan suhu terendah $22,45^{\circ} \mathrm{C}$ dan suhu tertinggi $35,7^{0} \mathrm{C}$. Kelembaban relative rata-rata tahunan adalah $86,9 \%$ dengan penyinaran matahari berkisar antara $42 \%$ sampai $71 \%$ atau rata-rata $53,9 \%$ (Badan Pusat Statistik Kabupaten Sintang, 2013).

\section{METODOLOGI PENELITIAN}

\section{Tempat dan Waktu Penelitian}

Penelitian ini dilaksankan di Kecamatan Kayan Hulu, mulai dilaksanakan pada bulan Februari sampai dengan bulan Juni 2017.

\section{Metode Penelitian}

Metode penelitian yang digunakan adalah metode penyelidikan deskriptif dengan pendekatan kualitatif yang tertuju pada pemecahan masalah yang ada dibatasi agar data-data yang diperoleh dapat digali serta tidak dimungkinkan adanya pelebaran objek penelitian. Objek dalam penelitian ini adalah jenis padi pulut lokal lahan kering yang terdapat di Kecamatan Kayan Hulu Kabupaten Sintang.

\section{Populasi dan Sampel}

Populasi dalam penelitian ini adalah seluruh jenis padi pulut lokal lahan kering yang terdapat di Kecamatan Kayan Hulu Kabupaten Sintang, sedangkan sampel tanaman yang diambil adalah 3 dari setiap jenis padi pulut lokal lahan kering yang didapat. Sampel lokasi yang diambil dalam penelitian ini adalah 5 desa dari 29 desa yang ada di Kecamatan Hulu yaitu Desa Nanga Ungai, Desa Buluh Merindu, Desa Nanga Toran, DesaTopan Nanga, Desa Empakan. Alasan pemilihan 5 desa ini karena berdasarkan informasi dari observasi awal diketahui bahwa kelima desa tersebut sebagian besar masyarakatnya masih membudidayakan padi pulut lokal lahan kering serta kelima desa tersebut memiliki tipologi kawasan yang beragam antara jalur Sungai Kayan dan Sungai Tebidah serta daerah perbukitan sehingga diharapkan jenis padi pulut lokal lahan kering yang ditemukan juga lebih beragam karena kondisi lingkungan yang berbeda antara daerah tepian sungai dan perbukitan. 


\section{Bahan Dan Alat Penelitian}

Bahan dalam penelitian ini adalah padi pulut lokal lahan kering yang ditemukan. Alat dalam penelitian ini adalah pedoman observasi, pedoman wawancara, kamera digital, dan alat tulis menulis.

\section{Pelaksanaan Penelitian}

Rangkaian kegiatan dalam penelitian ini adalah : penentuan daerah sampel, survey daerah sampel, pengumpulan data penunjang (kondisi wilayah, suhu,curah hujan, jenis tanah,), pengumpulan data utama (jenis dan morfologi padi pulut lokal lahan kering serta ketahanannya terhadap hama, penyakit dan gulma), wawancara, dan observasi.

\section{Pengumpulan Data}

Data utama yang diperoleh yaitu jenis dan karakteristik agronomis padi pulut lokal lahan kering tersebut dideskripsikan secara ringkas dan

ditabulasikan.

\section{HASIL DAN PEMBAHASAN}

\section{Hasil Penelitian}

Hasil penelitian yang dilakukan menemukan delapan jenis padi pulut lokal yang dibudidayakan pada lahan kering di Kecamatan Kayan Hulu Kabupaten Sintang yaitu pulut itam, pulut itam jabab, pulut kensurai, pulut lomak, pulut mentawak, pulut merah, pulut pantok manok, dan pulut payong. Kedelapan jenis padi pulut tersebut ditemukan pada dua tipe lokasi yaitu pada daerah tepian sungai yaitu Sungai Kayan dan Sungai Tebidah serta daerah perbukitan. Keseluruhan padi lokal yang ditemukan toleran terhadap hama, penyakit, kekeringan dan genangan akan tetapi peka terhadap kehadiran gulma. Gambaran ringkas tentang karakteristik morfologi kedelapan jenis padi pulut tersebut dirangkum dalam tabel berikut berikut : 
Tabel Karaketristik Jenis Padi Pulut Lokal Lahan Kering Di Kecamatan Kayan Hulu Kabupaten Sintang

\begin{tabular}{|c|c|c|c|c|c|c|c|}
\hline $\begin{array}{l}\mathrm{N} \\
\mathrm{O}\end{array}$ & $\begin{array}{c}\text { Jenis padi } \\
\text { pulut }\end{array}$ & $\begin{array}{c}\text { Lokasi } \\
\text { ditemukan }\end{array}$ & $\begin{array}{c}\text { Ciri dan gambar } \\
\text { akar }\end{array}$ & $\begin{array}{c}\text { Ciri dan gambar } \\
\text { batang }\end{array}$ & $\begin{array}{c}\text { Ciri dan gambar } \\
\text { daun }\end{array}$ & $\begin{array}{l}\text { Ciri dan gambar } \\
\text { bulir }\end{array}$ & $\begin{array}{c}\text { Ciri dan gambar } \\
\text { beras }\end{array}$ \\
\hline 1 & Pulut Itam & $\begin{array}{l}\text { Tepian } \\
\text { sungai }\end{array}$ & $\begin{array}{l}\text { Berakar serabut } \\
\text { dan penyebaran } \\
\text { perakaran relatif } \\
\text { pendek }\end{array}$ & $\begin{array}{l}\text { bentuk batang bulat } \\
\text { pangkal batang } \\
\text { berwarna hitam, } \\
\text { batang bagian atas } \\
\text { berwarna } \\
\text { kekuningan }\end{array}$ & $\begin{array}{l}\text { Naxill } \\
\text { Daun berwarna } \\
\text { hijau agak lancip } \\
\text { dan menyempit }\end{array}$ & $\begin{array}{l}\text { Warna bulir padi } \\
\text { cokelat berbentuk } \\
\text { lancip dibagian } \\
\text { ujung dan } \\
\text { memiliki garis } \\
\text { yang nyata di } \\
\text { tengahnya. }\end{array}$ & $\begin{array}{l}\text { Beras berwarna } \\
\text { hitam kemerahan }\end{array}$ \\
\hline 2 & $\begin{array}{l}\text { Pulut Itam } \\
\text { Jabab }\end{array}$ & $\begin{array}{l}\text { Tepian } \\
\text { sungai }\end{array}$ & $\begin{array}{l}\text { Berakar serabut } \\
\text { agak besar dan } \\
\text { penyebaran } \\
\text { perakaran relatif } \\
\text { pendek }\end{array}$ & $\begin{array}{l}\text { Batang berbentuk } \\
\text { bulat dan berwarna } \\
\text { hijau campur kuning }\end{array}$ & $\begin{array}{l}\text { foun } \\
\text { Daun berwarna } \\
\text { hijau terang dan } \\
\text { agak lebar }\end{array}$ & $\begin{array}{lr}\text { Bulir } & \text { padi } \\
\text { berwarna } & \text { hijau } \\
\text { muda dan agak } \\
\text { pendek }\end{array}$ & $\begin{array}{lr}\text { Beras } & \text { berwarna } \\
\text { dominan } & \text { putih } \\
\text { bercampur } & \text { hitam } \\
\text { sedikit } & \end{array}$ \\
\hline 3 & $\begin{array}{l}\text { Pulut } \\
\text { Kensurai }\end{array}$ & $\begin{array}{l}\text { Tepian } \\
\text { sungai }\end{array}$ & $\begin{array}{l}\text { Merakar serabut } \\
\text { dengan ukuran } \\
\text { agak besar tetapi } \\
\text { jangkauan } \\
\text { perakaran pendek }\end{array}$ & \begin{tabular}{l|l|l|} 
& \\
& & \\
Batang & berbentuk \\
bulat, & berwarna \\
dominan & kuning \\
bercampur hijau
\end{tabular} & $\begin{array}{l}\text { Daun berwarna } \\
\text { Dijau gelap } \\
\text { bercampur } \\
\text { semburat merah }\end{array}$ & $\begin{array}{l}\text { Bulir padi } \\
\text { berwarna } \\
\text { agak besar }\end{array}$ & $\begin{array}{lr}\text { Beras } & \text { berwarna } \\
\text { dominan } & \text { putih } \\
\text { bercampur coklat }\end{array}$ \\
\hline
\end{tabular}




\begin{tabular}{|c|c|c|c|c|c|c|c|}
\hline 4 & Pulut Lomak & $\begin{array}{l}\text { Tepian } \\
\text { sungai dan } \\
\text { perbukitan }\end{array}$ & $\begin{array}{lr} & \\
\text { Berakar } & \text { serabut } \\
\text { dengan } & \text { ukuran } \\
\text { sedang dan } & \text { sistem } \\
\text { perakaran } & \text { agak } \\
\text { luas } & \end{array}$ & $\begin{array}{l}\text { Batang bulat berwarna } \\
\text { hijau kekuningan }\end{array}$ & $\begin{array}{lr}\text { Daun r berwana } \\
\text { hijau terang } \\
\text { dengan ukuran } \\
\text { agak sempit }\end{array}$ & $\begin{array}{l}\text { Bulir padi } \\
\text { berbentuk pipih, } \\
\text { warna kuning dan } \\
\text { memiliki garis } \\
\text { tengah yang nyata }\end{array}$ & $\begin{array}{l}\text { Beras berwarna } \\
\text { putih bersih }\end{array}$ \\
\hline 5 & $\begin{array}{l}\text { Pulut } \\
\text { Mentawak }\end{array}$ & Perbukitan & $\begin{array}{l}\text { Berakar serabut } \\
\text { dengan } \\
\text { penyebaran agak } \\
\text { luas }\end{array}$ & $\begin{array}{l}\text { batang berwarna hijau } \\
\text { muda dan kekuningan }\end{array}$ & $\begin{array}{l}\text { Daun berwarna } \\
\text { hijau tua dengan } \\
\text { bercak cokelat di } \\
\text { tengah daun }\end{array}$ & $\begin{array}{l}\text { buah berwarna } \\
\text { kuning dan hijau } \\
\text { muda samar, } \\
\text { berbentuk kurus } \\
\text { memanjang } \\
\text { dengan garis } \\
\text { tengah yang nyata }\end{array}$ & $\begin{array}{l}\text { Beras berwarna } \\
\text { putih bersih tetapi } \\
\text { berukuran lebih } \\
\text { kecil namun agak } \\
\text { panjang dari beras } \\
\text { pulut lomak. }\end{array}$ \\
\hline 6 & Pulut Merah & Perbukitan & $\begin{array}{l}\text { P MU } \\
\text { Berakar serabut } \\
\text { dengan } \\
\text { penyebaran agak } \\
\text { luas }\end{array}$ & $\begin{array}{l}\text { Batang berbentuk } \\
\text { bulat berwarna hijau } \\
\text { muda }\end{array}$ & $\begin{array}{l}\text { Paun muda hijau } \\
\text { Daun } \\
\text { tua sedangkan } \\
\text { daun tua hijau } \\
\text { kekuningan }\end{array}$ & $\begin{array}{l}\text { Buah padi } \\
\text { berwarna cokelat } \\
\text { tua hampi merah, } \\
\text { garis tengah pada } \\
\text { buah terlihat } \\
\text { jelas, berbentuk } \\
\text { agak pipih }\end{array}$ & $\begin{array}{ll}\text { Beras } & \text { agak halus } \\
\text { dan } & \text { berwarna } \\
\text { merah. } & \end{array}$ \\
\hline
\end{tabular}




\begin{tabular}{|c|c|c|c|c|c|c|c|}
\hline 7 & $\begin{array}{l}\text { Pulut Pantok } \\
\text { Manok }\end{array}$ & $\begin{array}{l}\text { Perbukitan } \\
\text { dan tepian } \\
\text { sungai }\end{array}$ & $\begin{array}{l}\text { Berakar serabut, } \\
\text { agak besar dan } \\
\text { sebarannya agak } \\
\text { luas }\end{array}$ & 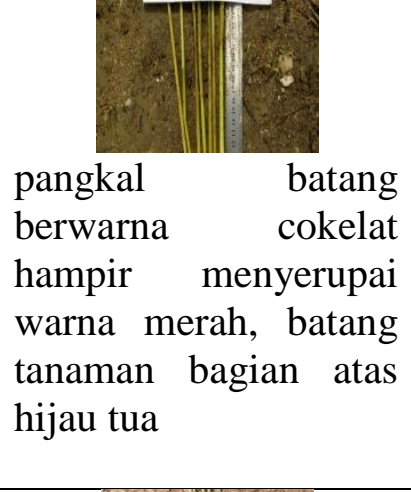 & $\begin{array}{lr}\text { Daun } & \text { berwarna } \\
\text { hijau } & \text { muda } \\
\text { dengan } & \text { bercak } \\
\text { cokelat } & \end{array}$ & $\begin{array}{l}\text { buah berwarna } \\
\text { kuning } r \text { agak } \\
\text { pucat, berbentuk } \\
\text { pipih dan pendek } \\
\text { dengan garis } \\
\text { tengah tidak } \\
\text { begitu nyata }\end{array}$ & $\begin{array}{l}\text { Beras berwarna } \\
\text { gelap bercampur } \\
\text { merah,ukuran beras } \\
\text { kecil. }\end{array}$ \\
\hline 8 & Pulut Payong & $\begin{array}{l}\text { Perbukitan } \\
\text { dan tepian } \\
\text { sungai }\end{array}$ & $\begin{array}{l}\text { Berakar serabut } \\
\text { dengan rambut } \\
\text { akar sangat nyata } \\
\text { terihat }\end{array}$ & \begin{tabular}{l||l} 
& \\
& \\
Pangkal & \\
berwarna katang \\
sedangkan bagian atas \\
berwarna hijau muda
\end{tabular} & 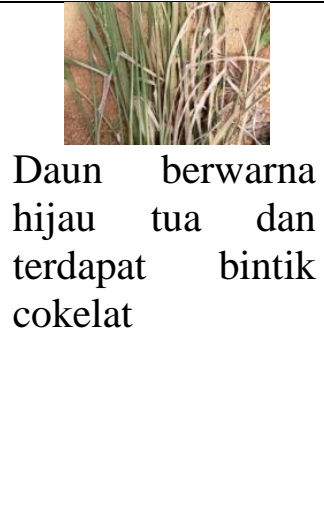 & $\begin{array}{l}\text { Buah padi } \\
\text { berwarna cokelat } \\
\text { dan pada kulit } \\
\text { buah terlihat jelas } \\
\text { menyerupai garis- } \\
\text { garis yang rata- } \\
\text { rata teridiri dari } \\
\text { tiga garis }\end{array}$ & $\begin{array}{l}\text { beras berwarna } \\
\text { putih bersih dan } \\
\text { berukuran agak } \\
\text { besar }\end{array}$ \\
\hline
\end{tabular}




\section{Pembahasan}

Karakteristik agronomis dari padi pulut lokal yang ditemukan pada saat penelitian menunjukkan perbedaan yang nyata terutama pada bagian akar. Jenis padi yang tumbuh di daerah tepian sungai yaitu padi itam, itam jabab, dan kensurai bentuk akar tanaman cenderung menyempit atau sebaran akar tidak meluas. Pada jenis padi yang tumbuh di daerah perbukitan seperti padi mentawak dan padi pulut merah bentuk akarnya memanjang dengan sebaran agak luas, sedangkan jenis padi yang dapat tumbuh pada daerah tepian sungai dan perbukitan seperti padi pulut lomak, pantok manok, dan payong bentuk akar tanaman menyebar dan berukuran agak besar. Hal ini merupakan bentuk adaptasi dari tanaman padi pulut lokal lahan kering dalam memenuhi kebutuhan unsur hara dan air. Menurut Budianta (2013) bahwa akar tumbuh-tumbuhan mempunyai hubungan penting dengan struktur tanah, kondisi air tanah, udara, dan unsur hara dalam horizon tanah.

Hasil wawancara dan observasi lapangan diketahui bahwa semua jenis padi pulut lokal lahan kering juga dapat tumbuh di daerah tergenang atau tumbuh lahan sawah tadah hujan.
Kemampuan adaptasi terhadap lingkungan ini disebabkan karena daya adaptasi yang tinggi terhadap kondisi lingkungan tumbuhnya. Balai Besar Penelitian Tanaman Padi (2015) menyatakan bahwa padi lokal dapat tumbuh pada berbagai jenis tanah, dari pH 3-10, kandungan bahan organik dari $1-50 \%$, dan pada kondisi tanah dengan kandungan hara yang rendah sampai tinggi. Tanaman padi pulut lokal tidak toleran terhadap kehadiran gulma disebabkan rendahnya daya saing tanaman dalam mendapatkan unsur hara dan ruang tumbuh, terutama pada saat tanaman masih muda. Hal ini sesuai dengan pendapat Sembodo (2010) yang menyatakan bahwa gulma merupakan salah satu faktor pembatas produksi tanaman, karena gulma menyerap air dan unsur hara lebih cepat dari tanaman budidaya.

\section{KESIMPULAN DAN SARAN}

Hasil penelitian menemukan delapan jenis padi pulut lokal lahan kering yang terdapat di Kecamatan Kayan Hulu Kabupaten Sintang yaitu pulut itam, pulut itam jabab, pulut kensurai, pulut lomak, pulut mentawak, pulut merah, pulut pantok manok, dan pulut payong yang tumbuh di dua tipe 
lahan yaitu tepian sungai dan perbukitan. Perlu dilakukan penelitian lebih lanjut tentang kandungan gizi pada masing - masing beras pulut tersebut.

\section{DAFTAR PUSTAKA}

Badan Pusat Statistik Kayan Hulu. 2016. Kecamatan Kayan Hulu Dalam Angka. Badan Pusat Statistik. Nanga Tebidah.

Badan Pusat Statistik Kabupaten Sintang, 2013. Kabupaten Sintang Dalam Angka. Badan Pusat Statistik. Sintang.

Balai Besar Penelitian Tanaman Padi. 2015. Jenis Tanah dan Profil Lahan Padi Gogo. Agroinovasi: Balai Besar Penelitian Tanaman Padi. Balitbangtan. Kementerian Pertanian. Agustus 2015.

Budianta, D. 2013. Hubungan Air dan Tanaman. Fakutas Pertanian UNSRI Palembang.

Direktorat Jenderal Perbenihan

Tanaman Pangan. 2010.

Penyebaran varietas padi di
Indonesia. Kementerian Pertanian. Jakarta.

Harahap, Z., dan T.S. Silitonga. 1989. Perbaikan Varietas Padi Jilid II. Pusat Penelitian Dan Pengembangan Tanaman Pangan. Bogor.

Ifadatin, S., E. Rusmiyanto. 2006. Keanekaragaman Genetik Padi Lokal Kalimantan Barat Berdasarkan Penanda Izozim. Jurnal Floribunda. Vol. 3. No. 4. 2006.

Kamus Besar Bahasa Indonesia. 2016. KBBI Online. www.kbbi.co.id.

Ningsih, D.L. 2016. Manfaat Beras Ketan Untuk Kesehatan. viva.co.id. Rabu 2 November 2016. 10:58 WIB.

Sembodo, DRJ. 2010. Gulma dan Pengelolaannya. Graha Ilmu. Yogyakarta

Sitaresmi, T., R. H. Wening, A.T. Rakhmi., N. Yunani., U. Susanto. 2013. Pemanfaatan Plasma Nutfah Padi Varietas Lokal dalam Perakitan Varietas Unggul. IPTEK TANAMAN PANGAN VOL. 8 NO. 1 2013. 